\title{
Community Based Sprinkler Irrigation System for Groundwater Sharing in Ananthapur District of Andhra Pradesh, India
}

\author{
S. Deepika ${ }^{1 *}$, K.V. Rao ${ }^{1}$, R. Rejani $^{1}$, B. Krishna Rao ${ }^{1}$ and A.P. Mukherjee ${ }^{2}$ \\ ${ }^{1}$ ICAR-Central Research Institute for Dryland Agriculture, Hyderabad, India \\ ${ }^{2}$ Indira Gandhi Krishi Vishvavidyalaya, Raipur, Chattisgarh, India \\ *Corresponding author
}

\begin{abstract}
A B S T R A C T
Groundwater sharing using Community Based Sprinkler Irrigation System (CBSIS) is an optimal way of using groundwater to protect kharif crops in semiarid regions. CBSIS designs were studied in three mandals viz. Garladinne, Nallamada and Goothy of Ananthapur district, Andhra Pradesh in India. The study aims to assess the existing irrigation system designs and to evaluate the existing operational schedules and preparation of optimal operational plans in terms of equity of water sharing. The major findings in the sites are to fix the overhead sprinklers at 30 or 50 percent overlapping. Instead of giving one or two critical irrigations, it is possible to provide recommended irrigation schedules even in Non Bore Well Owners (NBWO) land by adopting crop wise operating schedules for the three groups with the available water. Sprinkler heads which are presently used can meet the crop water requirement (CWR) of groundnut within 16 to 18 min during kharif and rabi seasons respectively. Total number of irrigations required for groundnut during kharif and rabi are 10 and 12 respectively with an irrigation frequency of 11 days (without considering rainfall). Following the recommended schedules Mahabubsubhani group can irrigate 14.7 ha/day whereas Eedulavanka group and T-Kothapally group can irrigate to $6.26 \mathrm{ha} /$ day and 4.7 ha/day respectively.
\end{abstract}

\section{Keywords}

Community sprinkler irrigation designs,

Operating schedules,

Optimal operational plans

Article Info

Accepted:

24 August 2018

Available Online:

10 September 2018

\section{Introduction}

Declining groundwater levels are very common in India especially under dryland conditions. So farmer has to adopt advanced technology which is accessible such as pressurized irrigation system, porous pipe irrigation, precision farming, etc. for conserving water and to increase the efficiency. The term efficiency technically means adopting proper scheduling at field level (Knox et al., 2012). The prime objective of applying water to the plant is according to its requirement which is determined by soil, environment conditions and many other factors. Though agriculture remains the most important economic activity of rural India, most of the farmers are leaving the lands barren due to lack of water for irrigation due to failure of bore wells (Seckler et al., 1998). The institutional approach is to manage groundwater by arresting over-exploitation of groundwater and for mitigating environmental consequences through establishment of a 
regulatory framework. Towards this end, the Government of Andhra Pradesh introduced the Andhra Pradesh Drought Adaptation Initiative (AP DAI) implemented in Ananthapur district. The project aims to protect kharif crops during prolonged dry spell by pooling the bore wells to share water among Bore Well Owners (BWO) and Non Bore Well Owners (NBWO) by forming a community based irrigation system (Bedeke, 2011; Hector et al., 2011; Rao et al., 2017).

Despite the fact that Ananthapur district falls under rain shadow region, agriculture remains the important source for economic activity (Seckler et al., 1998). Due to irregular and improper distribution of rainfall, irrigation is necessary to protect the rainfed crop and increase the productivity of agriculture produce (Murty et al., 2007). Micro irrigation is a good alternative for the arid and semiarid regions as it is the modern irrigation technology suitable for almost all crops and climatic conditions. Hence, the focus of this study is to analyze the designs of CBSIS and develop recommendations to improve the system performance and efficiency with the available resources and preparation of optimal operational plan for the group of pooled farmers.

\section{Materials and Methods}

Groundwater sharing aims to protect kharif crops during prolonged dry spells by pooling the bore wells to share water among Bore well Owners (BWO) and Non Bore Well Owners (NBWO) by forming a community (Reddy et al., 2012). In this study, three farmer groups were identified. Each of the farmers from the three groups was interviewed personally to find the prevailing site conditions, operation methods and strategies followed. The designs of semi-permanent sprinkler irrigation system (SPSIS) have been prepared for the three CBSIS groups located in three different mandals (cluster of villages) of Ananthapur district. Assessment of optimal operational schedules, by using the crop water requirement and available water plays the key role for the success of community based sprinkler irrigation system. Hence, three groups were randomly selected out of 14 in the district and suitable SPSIS designs and operational schedules were prepared for the available resources. The selected sites were surveyed and plotted using Auto CAD 2007.

\section{Study area}

Ananthapur district is in the southern part of Andhra Pradesh and is located in the rain shadow region. Available water in the study area and the site conditions are detailed in the Table 1. Three groups were selected from three different mandals located in Ananthapur district namely, Yarraguntla village of Garladinnemandal, $\mathrm{T}$ Kothapally village of Gootymandal and Eedulavanka village of Nallamadamandal.

\section{Climatic and soil conditions}

Out of $553 \mathrm{~mm}$ of normal rainfall in Ananthapur district, $330 \mathrm{~mm}$ was received during south west monsoon (June to September) i.e. during kharif season. The soils of these regions are mostly red soils and the texture is loam to sandy loam. This is mostly suited to irrigated and dry land crops. The average depth of soils is $180 \mathrm{~cm}$ while the depth of top layer is nearly $40-50 \mathrm{~cm}$ covering one third of the soil depth (Rukmani and Manjula, 2010).

\section{Water available}

Availability of water is measured during summer season by collecting the water in a container of known capacity and the time required to fill is noted. The pump has been operated for 6 hrs to know whether there is 
any variation in discharge if the pump is operated continuously. After finding the safe discharges of the bore well, the irrigation system has been designed.

\section{Assessment of suitability of the irrigation system}

Farmers who are getting water from the bore well owners to meet the critical irrigation for protecting the rainfed crops (kharif crop) needs to utilize the water efficiently. It is already proven that the field application efficiency is highest for drip irrigation followed by sprinkler irrigation, furrow and then border irrigation (Brouwer et al., 1989). In order to meet the irrigation requirement of the crops with the available water sources, fund available and government policies, sprinkler irrigation system was selected in all the three mandals (Christiansen, 1942; Pritee et al., 2014). The factors considered to evaluate the design are net depth of water application, irrigation frequency, operating hours and operating schedules (Hill and Heaton, 2001). Operating pressure required for sprinkler irrigation intended for uniform drop let size and wetting pattern is $2.5 \mathrm{~kg} / \mathrm{m}^{2}$.

\section{Net depth of water application $\left(D_{\text {net }}\right)$}

The depth of water application is the quantity of water which should be applied during irrigation to meet the crop evapo-transpiration and the computation of the net depth of water application is calculated using Eqn 1.

$$
D_{\text {net }}=(F C-P W P) x(P) x(R Z D)
$$

Where, $D_{\text {net }}$ is net depth of water application per irrigation for the selected crop $(\mathrm{mm}), \mathrm{FC}$ is soil moisture at field capacity $(\mathrm{mm} / \mathrm{m})$, PWP is soil moisture at the permanent wilting point $(\mathrm{mm} / \mathrm{m})$, RZD is the depth of soil that the roots extract water and nutrients effectively (m), Pis the allowable portion of available moisture permitted for depletion by the crop before the next irrigation (generally considered as $50 \%$ depletion)

\section{Available soil moisture}

The difference between field capacity and permanent wilting point will give the available soil moisture (water holding capacity), which is the total amount of water that the crop can use depending on the crop sensitivity to stress. Available soil moisture for sandy loam ranges from $90-150 \mathrm{~mm} / \mathrm{m}$. Depth of root zone considered for groundnut is 0.5 to $1.0 \mathrm{~m}$, pigeon pea is 0.7 to $1.5 \mathrm{~m}$, maize is 1.0 to 1.7 $\mathrm{m}$ and tomato is 0.5 to $0.6 \mathrm{~m}$ (FAO, 2001). Therefore, the average value is considered for calculating the depth of irrigation.

\section{Irrigation frequency}

Irrigation frequency is the time it takes the crop to deplete the soil moisture at a given soil moisture depletion level. After establishing the net depth of water application, the irrigation frequency at peak water demand can be determined using the following Eqn.2

$$
\text { Irrigationfrequency }(I F)=\frac{D_{\text {net }}}{W U}(2)
$$

Where, IF irrigation frequency (days), $\mathrm{D}_{\text {net }}$ is net depth of water application $(\mathrm{mm})$, WU is peak daily water use (mm/day).

\section{Operating hours}

Operating hours is the time to which each section or the sprinkler set has to be operated to meet the irrigation requirement and is determined using Eqn.3

Operating hours $=\frac{P W R}{A R}$ 
Where, PWR is peak water requirement $\left(1 / \mathrm{m}^{2} /\right.$ day $)$ and AR is application rate $\left(1 / \mathrm{hr} / \mathrm{m}^{2}\right)$ Application rate (AR) is the rate at which water is applied to a particular area was estimated as in Eqn.4

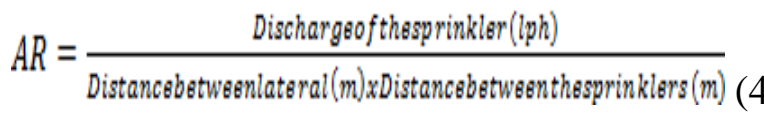

\section{Number of rotations in a day}

The number of rotations depends on the available water, number of sprinkler sets and discharge of each sprinkler set (Eqn. 5)

Rotationsper day $=\frac{Q}{(\text { Dischargeofsprinklerset }) x(\text { No. of sets })}(5)$

Where, Q is total discharge of the bore wells in lph and discharge of the sprinkler set is in lph.

The management practices followed by the beneficiaries in CBSIS adapted areas and the type of the crops grown are of paramount importance to the water resource utilization pattern and its development. These factors are ultimately reflected in terms of increased cultivated area and crop production and hence their assessment is necessary.

\section{Results and Discussion}

Net depth of water application and irrigation frequency

Net depth of water application and irrigation frequency for the major crops in red soil considering the $150 \mathrm{~mm} / \mathrm{m}$ of available soil moisture has been assessed. Net depth of water application for groundnut is $75 \mathrm{~mm}$ with $1 \mathrm{~m}$ of root zone depth. Similarly for pigeon pea, the net depth of application and root zone are $112.5 \mathrm{~mm}$ and $1.5 \mathrm{~m}$, for maize it is 127.5 $\mathrm{mm}$ and $1.7 \mathrm{~m}$ and for tomato with $0.6 \mathrm{~m}$ of root zone depth is $45 \mathrm{~mm}$ net depth of water application. Irrigation frequency was obtained for four major crops during kharif and rabi. Groundnut requires 10 irrigations during kharif and 11 during rabi with an irrigation interval of 11 and 10 days respectively (without considering the rainfall) for110 days of the crop growing period. Similarly for pigeon pea with 170 days of growing period requires 10 irrigations with 17 days of irrigation interval, Maize when considered for 120 days requires 6 and 5 irrigations with an interval of 18 and 22 days during kharif and rabi respectively. Tomato with 145 days of crop period requires 24 irrigations with 6 days of interval during kharif and rabi.

\section{Estimation of operating schedules for CBSIS}

\section{Prevailing operating schedules}

Interaction with the farmers revealed that bore well owners are irrigating the field everyday by leaving each set to operate for $3 \mathrm{hrs}$ and then shifting to second patch operating again for $3 \mathrm{hrs}$ resulting in over irrigation. In turn, this is leading to deep percolation of water below the root zone, leaching of micronutrients and wastage of pumped water and erosion of soil. Spacing between sprinkler to sprinkler and lateral to lateral is $12 \mathrm{~m}$ which is being maintained in all the fields without overlapping Figure 1. NBWO were getting only the critical irrigation once or twice during the crop period. Modifications can be adopted and can be admitted by all the members of the group are detailed further.

Site wise recommended operating schedules

\section{Yerraguntla, Mahabubsubhani group}

With the available resources to achieve maximum yields, operational schedules are planned according to the available water by dividing the total group into 5 to 6 sub divisions and can be irrigated in 5 to 6 days. 
With the available water each group of 9.43 ha could be irrigated every day by operating each set for $16.24 \mathrm{~min}$ to meet the water requirement (WR) for groundnut. But to irrigate 9.43 ha per day, this group may require 4 additional sprinkler sets. So, alternative operation schedule is planned according to the available water and number of sprinkler sets with the group.

Considering $6 \mathrm{~h}$ of power per day and with the available sets of sprinkler units, 8.05 ha and 6.81 ha can be irrigated per day during kharif and rabi seasons respectively, by considering $30 \mathrm{~min}$ for each operation along with grace period for shifting the unit. Without considering the precipitation during kharif entire area of the group can be irrigated in 5 days however during rainy season few irrigations can be skipped according to precipitation.

\section{Dunnikota, Eedulavanka group}

Though the number of subdivisions required is two during kharif and thre during rabi as per the available water. But this group is having only 8 sprinkler sets, so, scheme of operation has been planned to suit that.

Following the same procedure, the land holding of 17.81 ha of this group can be irrigated by sub dividing into 5 sections and each in a day. Time of operation for each section is considered for $30 \mathrm{~min}$, providing some grace period for shifting. Maximum 3.64 ha can be irrigated in a section per one day.

\section{TKothapally, Gangireddygroup}

This group has a holding of 9.71 ha and 6 sprinkler sets with an available water $194 \mathrm{~m}^{3} /$ day. Accordingly maximum 2.98 ha can be irrigated per day. The total WR of the group can be met within 4 days.

\section{Design of community based micro}

Table.1 Details of farming profile for the three selected groups

\section{irrigation system}

The design adapted in the field was assessed in a view to check the feasibility to improve with the present available resources. For all the groups, sprinkler system has been sanctioned and the technical norms were as per the guiding principles of Andhra Pradesh micro Irrigation Project (APMIP). The sprinkler set sanctioned was of 5 lengths of 75 mm HDPE pipe (each 6m length), 5 sprinkler nozzles with discharge the $0.5 \mathrm{l} / \mathrm{s}$ and with radius of throw $6 \mathrm{~m}$, raiser pipes and fittings. Number of sets sanctioned was based on the availability of fund as per the budget allotment to the group, size of group and number of farmers participating.

Before starting sprinkler irrigation design, the basic considerations were application rate and the spacing of the sprinklers. The application rate should be such that there should not be any runoff or stagnant water patches on the surface, the sprinkler application rate should not exceed the basic soil infiltration rate. The sprinklers has to be placed in such a way that there won't be any dry patches in between.

The optimum spacing for the nozzle size selected was $8.4 \mathrm{~m} \times 8.4 \mathrm{~m}$ with $30 \%$ overlapping Figure 2 (a) and the ideal spacing would be with $50 \%$ overlapping. It is known that micro irrigation is the application of precise amount of water for a long duration. The efficiency of water can be improved by selecting a sprinkler head that discharges water which suits infiltration rate of the soil and it also arrests the soil erosion problem.

\section{Assessment of sprinkler irrigation system design}

Designs of CBMIS of three groups suitable with the available resources are detailed below. 


\begin{tabular}{|c|c|c|c|c|c|c|c|}
\hline \multirow[t]{2}{*}{ Group Name } & \multicolumn{2}{|c|}{ BWO } & \multicolumn{2}{|c|}{ NBWO } & \multirow{2}{*}{$\begin{array}{c}\text { No. } \\
\text { of } \\
\text { bore } \\
\text { wells }\end{array}$} & \multirow{2}{*}{$\begin{array}{c}\text { A vailable } \\
\text { water (6h of } \\
\text { pumping) } \\
\text { (m³/ day) }\end{array}$} & \multirow{2}{*}{$\begin{array}{l}\text { Total } \\
\text { area } \\
\text { (ha) }\end{array}$} \\
\hline & $\begin{array}{c}\text { No. of } \\
\text { Farmers }\end{array}$ & $\begin{array}{c}\text { Area } \\
\text { (ha) }\end{array}$ & $\begin{array}{l}\text { No. of } \\
\text { Farmers }\end{array}$ & $\begin{array}{c}\text { Area } \\
\text { (ha) }\end{array}$ & & & \\
\hline Mahabubsubhani & 4 & 4.86 & 21 & 32.89 & 7 & 724 & 37.75 \\
\hline Eedulavanka & 7 & 8.91 & 12 & 8.91 & 7 & 621.86 & 17.82 \\
\hline Mamidimandla & 4 & 2.43 & 13 & 7.29 & 4 & 195 & 9.72 \\
\hline
\end{tabular}

Table.2 (a) Water requirement (mm/day) for kharif and rabi crops for Yerraguntal Mahabobsubhani group

\begin{tabular}{|c|c|c|c|c|c|c|c|}
\hline Parameters & $\begin{array}{l}\text { Groundnut } \\
\qquad(K)\end{array}$ & $\begin{array}{l}\text { Pigeon } \\
\text { pea }(K)\end{array}$ & $\begin{array}{l}\text { Maize } \\
(K)\end{array}$ & $\begin{array}{l}\text { Tomato } \\
(K)\end{array}$ & $\begin{array}{l}\text { Groundnut } \\
(R)\end{array}$ & $\begin{array}{l}\text { Maize } \\
(\boldsymbol{R})\end{array}$ & $\begin{array}{l}\text { Tomato } \\
(\boldsymbol{R})\end{array}$ \\
\hline $\begin{array}{l}\text { Peak Water } \\
\text { requirement, } \\
\text { mm/day }\end{array}$ & 6.90 & 6.67 & 6.90 & 7.20 & 7.87 & 5.89 & 7.35 \\
\hline $\begin{array}{l}\text { Water required, } \\
\mathbf{m}^{3} / \mathrm{ha}\end{array}$ & 69.00 & 66.70 & 69.00 & 72.00 & 78.70 & 58.90 & 73.50 \\
\hline $\begin{array}{l}\text { Net depth of } \\
\text { irrigation, } \mathrm{mm}\end{array}$ & 75 & 112.5 & 127.5 & 45 & 75 & 127.5 & 45 \\
\hline $\begin{array}{l}\text { Irrigation } \\
\text { Frequency, days }\end{array}$ & 11 & 17 & 18 & 6 & 10 & 22 & 6 \\
\hline $\begin{array}{l}\text { No. of irrigations } \\
\text { required }\end{array}$ & 10 & 10 & 6 & 23 & 12 & 6 & 24 \\
\hline $\begin{array}{l}\text { Total water } \\
\text { requirement for } \\
32.89 \mathrm{ha}^{3} \mathrm{~m}^{3}\end{array}$ & 2269 & 2194 & 2269 & 2368 & 2588 & 1937 & 2417 \\
\hline $\begin{array}{l}\text { Water } \\
\text { requirement for } \\
4.86 \mathrm{ha}, \mathrm{m}^{3}\end{array}$ & 335 & 324 & 335 & 350 & 382 & 286 & 357 \\
\hline $\begin{array}{l}\text { Water } \\
\text { requirement for } \\
37.75 \mathrm{ha}, \mathrm{m}^{3}\end{array}$ & 2437 & 2356 & 2437 & 2543 & 2780 & 2080 & 2596 \\
\hline No. of Sections & 3 & 3 & 3 & 3 & 4 & 3 & 3 \\
\hline
\end{tabular}


Table.2 (b) Design data of Mahabubsubhani, Eedulavanka and T Kothapally groups

\begin{tabular}{|c|c|c|c|}
\hline \multirow{2}{*}{ Details } & \multicolumn{3}{|c|}{ Group Name } \\
\hline & Mahabubsubhani | & Eedulavanka & TKKothapally \\
\hline No of borewells & 7.00 & 7.00 & 4.00 \\
\hline $\begin{array}{l}\text { Pumping capacity of the bore wells per day, } \\
\mathrm{m}^{3} / 6 \mathrm{~h}\end{array}$ & 1313.50 & 1731.38 & --- \\
\hline Actual total available water in the block, $\mathrm{m}^{3} / \mathrm{day}$ & 724.00 & 621.86 & 195.00 \\
\hline Total head loss in conveyance & 21.00 & 21.00 & 15.00 \\
\hline Topography, m & 5.00 & 1.50 & 4.50 \\
\hline $\begin{array}{l}\text { Required operating pressure for sprinkler } \\
\text { system, m }\end{array}$ & 25.00 & 25.00 & 25.00 \\
\hline Dicharge of sprinkler, Ips & 0.50 & 0.50 & 0.50 \\
\hline Dicharge of sprinkler set, Ips & 2.50 & 2.50 & 2.50 \\
\hline Crop water requirement (groundnut), $\mathrm{mm} / \mathrm{day}$ & 6.90 & 6.90 & 6.90 \\
\hline $\begin{array}{l}\text { Crop water requirement (groundnut), } \\
\text { mºy/ha }^{3} / \text { day/ha }\end{array}$ & 69.00 & 69.00 & 69.00 \\
\hline $\begin{array}{l}\text { Area can be irrigated with the available water } \\
\text { per day, ha }\end{array}$ & 10.49 & 9.01 & 2.83 \\
\hline Area of Bore well Owners (BWO), ha & 4.86 & 8.91 & 2.43 \\
\hline Total water required to irrigate BWO field, $\mathrm{m}^{3}$ & 335.22 & 614.79 & 167.61 \\
\hline Area of Non Bore well Owners (NBWO), ha & 32.89 & 8.91 & 7.29 \\
\hline $\begin{array}{l}\text { Total water required to irrigate NBWO field, } \\
\mathrm{m}^{3}\end{array}$ & 2269.74 & 614.79 & 502.83 \\
\hline Spacing between sprinklers, $\mathrm{m}$ & 8.40 & 8.40 & 8.40 \\
\hline Spacing between lateral, $\mathrm{m}$ & 8.40 & 8.40 & 8.40 \\
\hline Application rate, $\mathrm{mm} / \mathrm{h}$ & 25.50 & 25.50 & 25.50 \\
\hline Operating time of each section, min & 16.23 & 16.23 & 16.23 \\
\hline Net depth of irrigation for groundnut, $\mathrm{mm}$ & 75.00 & 75.00 & 75.00 \\
\hline Irrigation frequency & 11.00 & 11.00 & 11.00 \\
\hline Power available per day, $h$ & 7.00 & 7.00 & 7.00 \\
\hline No. of rotations in $6 \mathrm{~h}$ & 22.18 & 22.00 & 22.00 \\
\hline No of sprinkler sets available with the block & 18.00 & 8.00 & 6.00 \\
\hline Discharge required to operate each set, $\mathrm{m}^{3} / \mathrm{h}$ & 9.00 & 9.00 & 9.00 \\
\hline Discharge required to operate 2 sets, $\mathrm{m}^{3} / \mathrm{h}$ & 18.00 & 18.00 & 18.00 \\
\hline Carrying capacity of $75 \mathrm{~mm}$ pipe, $\mathrm{m}^{3} / \mathrm{h}$ & 18.00 & 18.00 & 18.00 \\
\hline $\begin{array}{l}\text { Area can be irrigated as one section, ac ( } 2 \\
\text { sprinkler sets) }\end{array}$ & 0.07 & 0.07 & 0.07 \\
\hline $\begin{array}{l}\text { Main line of } 90 \mathrm{~mm} \text { diameter can carry water, } \\
\mathrm{m}^{3} / \mathrm{h}\end{array}$ & 40.00 & 36.00 & 36.00 \\
\hline Area can be irrigated at a time, ha & 0.16 & 0.14 & 0.14 \\
\hline $\begin{array}{l}\text { Total area can be irrigated with available water } \\
\text { per day, ha }\end{array}$ & 10.49 & 9.01 & 2.83 \\
\hline
\end{tabular}


Table.3 Water requirement ( $\mathrm{mm} /$ day) for kharif and rabi crops for Eedulavanka group

\begin{tabular}{|c|c|c|c|c|c|c|c|}
\hline Parameters & $\begin{array}{l}\text { Groundnut } \\
\qquad(\boldsymbol{K} h)\end{array}$ & $\begin{array}{l}\text { Pigeon } \\
\text { Pea } \\
(K / h)\end{array}$ & $\begin{array}{l}\text { Maize } \\
(\boldsymbol{K h})\end{array}$ & $\begin{array}{l}\text { Tomato } \\
(K h)\end{array}$ & $\begin{array}{l}\text { Groundnut } \\
(R)\end{array}$ & $\begin{array}{l}\text { Maize } \\
(\boldsymbol{R})\end{array}$ & $\begin{array}{l}\text { Tomato } \\
\text { (R) }\end{array}$ \\
\hline $\begin{array}{l}\text { Water required } \\
\mathbf{m}^{\mathbf{3}} / \mathbf{h a}\end{array}$ & 69 & 67 & 69 & 72 & 79 & 59 & 74 \\
\hline $\begin{array}{l}\text { Irrigation frequency, } \\
\text { days }\end{array}$ & 11 & 17 & 18 & 6 & 10 & 22 & 6 \\
\hline $\begin{array}{l}\text { No. of irrigations } \\
\text { required }\end{array}$ & 10 & 10 & 6 & 23 & 12 & 6 & 24 \\
\hline 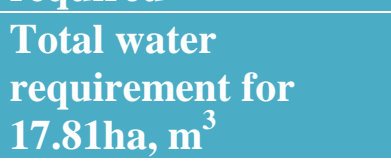 & 1229 & 1188 & 1229 & 1282 & 1402 & 1049 & 1309 \\
\hline $\begin{array}{l}\text { Total water } \\
\text { requirement for } \\
8.91 \mathrm{ha}, \mathrm{m}^{3}\end{array}$ & 615 & 594 & 615 & 642 & 1731 & 1296 & 1617 \\
\hline $\begin{array}{l}\text { Total water } \\
\text { requirement for } \\
8.91 \mathrm{ha}, \mathrm{m}^{3}\end{array}$ & 615 & 594 & 615 & 642 & 1731 & 1296 & 1617 \\
\hline No. of Sections & 2 & 2 & 2 & 2 & 2 & 2 & 3 \\
\hline
\end{tabular}

Table.4 Water requirement (mm/day) for kharif and rabi crops for T Kothapally group

\begin{tabular}{|c|c|c|c|c|c|c|c|}
\hline Parameters & $\begin{array}{l}\text { Groundnut } \\
(\boldsymbol{K} \boldsymbol{h})\end{array}$ & $\begin{array}{c}\text { Pigeon } \\
\text { Pea } \\
(\boldsymbol{K h})\end{array}$ & $\begin{array}{l}\text { Maize } \\
(K h)\end{array}$ & $\begin{array}{l}\text { Tomato } \\
(\boldsymbol{K} h)\end{array}$ & $\begin{array}{l}\text { Groudnut } \\
\quad(R)\end{array}$ & $\begin{array}{l}\text { Maize } \\
(\boldsymbol{R})\end{array}$ & $\begin{array}{l}\text { Tomato } \\
\text { (R) }\end{array}$ \\
\hline $\begin{array}{l}\text { Water required } \\
\mathbf{m}^{3} / \mathbf{h a}\end{array}$ & 69 & 67 & 69 & 72 & 79 & 59 & 74 \\
\hline $\begin{array}{l}\text { Irrigation } \\
\text { frequency, days }\end{array}$ & 11 & 17 & 18 & 6 & 10 & 22 & 6 \\
\hline $\begin{array}{l}\text { No. of irrigations } \\
\text { required }\end{array}$ & 10 & 10 & 6 & 23 & 12 & 6 & 24 \\
\hline $\begin{array}{l}\text { Total Water } \\
\text { requirement for } \\
9.72 \mathrm{ha}, \mathrm{m}^{3}\end{array}$ & 671 & 648 & 671 & 700 & 765 & 573 & 714 \\
\hline $\begin{array}{l}\text { Water } \\
\text { requirement for } \\
2.43 \mathrm{ha}, \mathrm{m}^{3}\end{array}$ & 168 & 162 & 168 & 175 & 191 & 143 & 179 \\
\hline $\begin{array}{l}\text { Water } \\
\text { requirement for } \\
7.29 \mathrm{ha}, \mathrm{m}^{3}\end{array}$ & 503 & 486 & 503 & 525 & 574 & 429 & 536 \\
\hline No. of Sections & 4 & 4 & 4 & 4 & 4 & 3 & 4 \\
\hline
\end{tabular}


Fig.1 Over irrigation existing in the farmers field

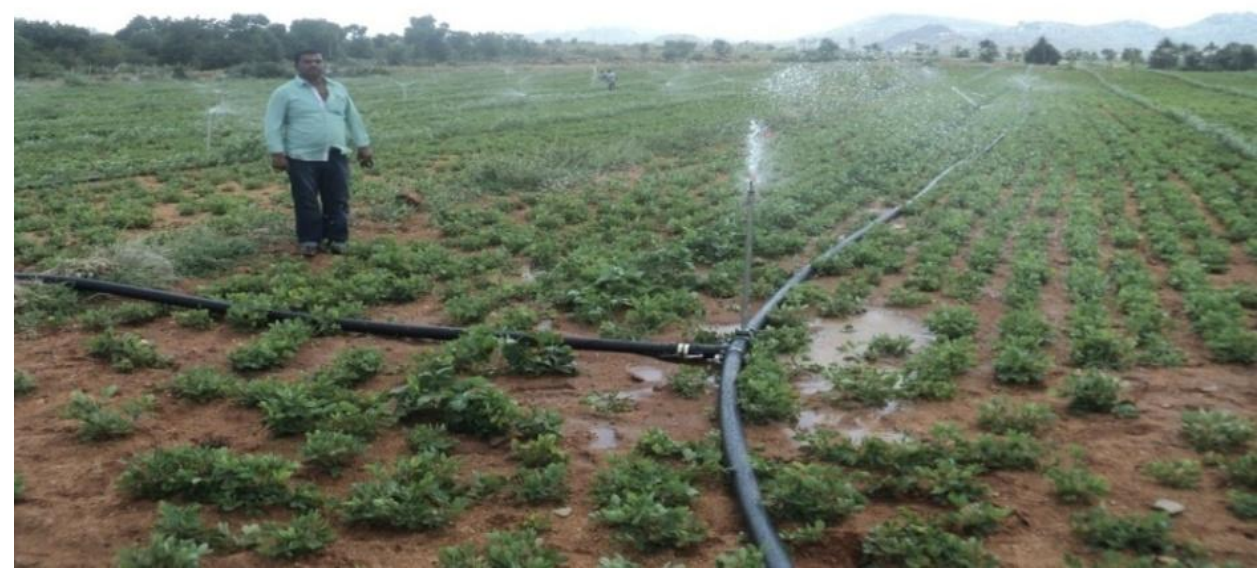

Fig.2 (a) Distribution of wetting pattern, (b) Layout sketch of Yerraguntla, (c) Layout of Eedulavanka group and (d) Layout of T Kothapally group

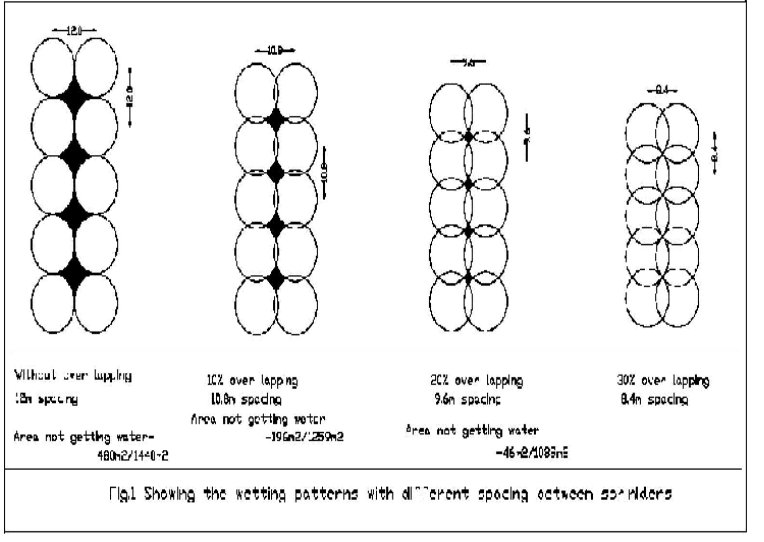

(a)

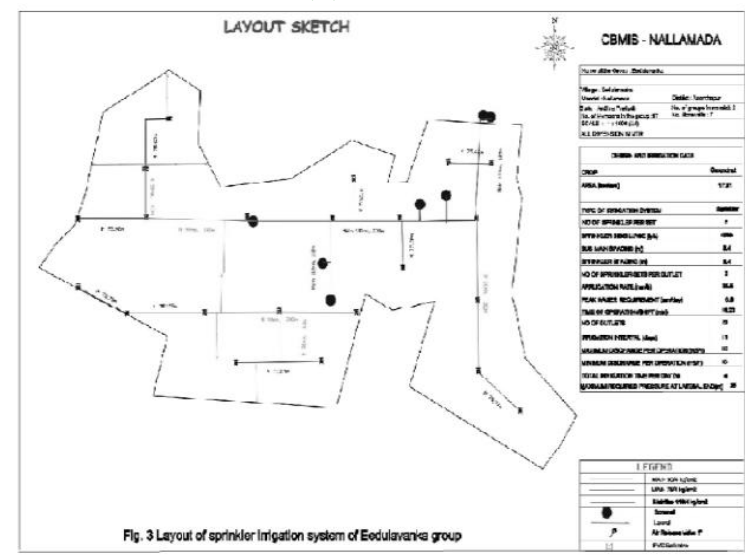

(c)

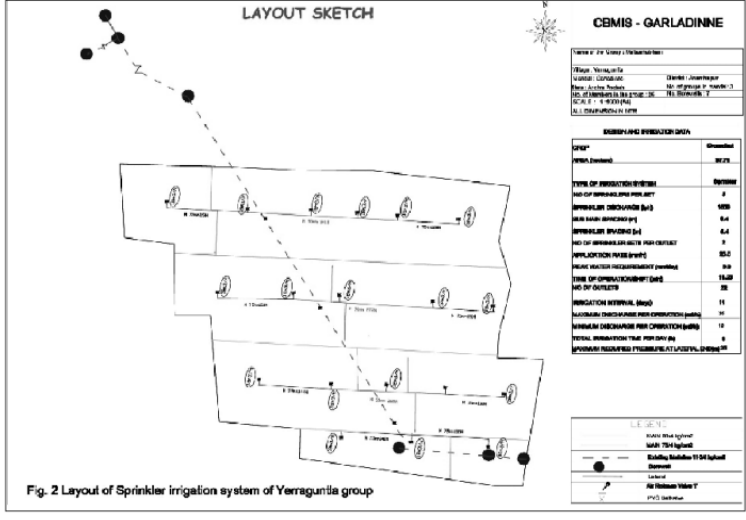

(b)

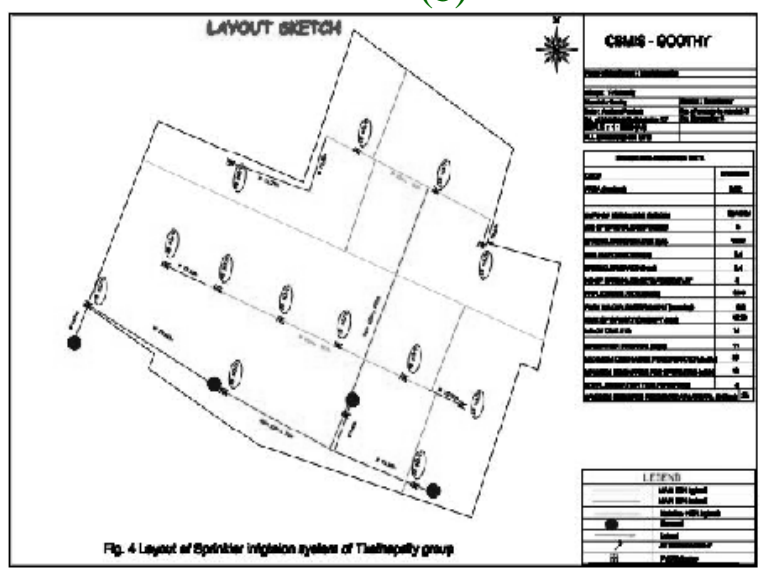

(d) 
Yerraguntla, Mahabubsubhani group CBMIS

In this group, out of 25 farmers, four farmers own seven bore wells, and sharing water among non borewell owners to meet critical irrigation during kharif season. The major crop grown during kharif and rabi is groundnut. The borewell discharges were measured during summer and considered in assessing the available water.

\section{Site conditions}

Four borewells are located outside the field which is $2500 \mathrm{~m}$ away from the CBMIS group. Pipe line is already existing which is connecting the rest of the three borewells as they belong to the same family. The maximum pipe size that is available under APMIP is $110 \mathrm{~mm}$ that has been laid to pool all the seven borewells.

The layout of the site is shown in Figure 2(b). Around $20 \%$ of actual discharge measured at the $\mathrm{BW}$ points is deducted to consider the head loss in pipe line during conveyance. System was designed to meet the irrigation requirement with the available (existing) sizes of conveyance system. This group has 18 sets of sprinkler units. The available area which can be irrigated is assessed considering the peak water requirement (PWR) of groundnut. Actually the system is designed to irrigate BWO field and share water to NBWO only to save the crop during prolonged dry span during kharif season. But it is observed that borewells are being operated daily to irrigate the BWO field which is only 4.86 ha. Whereas water required to irrigate 4.86 ha is $335 \mathrm{~m}^{3}$ and total water required during the crop period is $3686 \mathrm{~m}^{3}$ ( 3 months). So, instead of only critical irrigation the rest of the water which is being pumped every day can be shared among the NBWO farmers so that their crop yields can be improved in an area of 32.89 ha, which is connected with the borewell system.

To meet the irrigation requirement of total field (37.75 ha), irrigation system can be planned in such a way that without over irrigating the patch and leaving the sprinkler set ideal while shifting the unit to other patch. Entire 18 sets have to be used as single unit according to the pressure availability instead of using single set by one farmer. Proposed design show the area can be irrigated using 2 sprinkler sets with $30 \%$ overlapping and providing optimal irrigation as per PWR of particular crop. Therefore, with the available water (pumped for $6 \mathrm{~h} /$ day), total area can be irrigated within 4 days. Crop wise WR and design data are shown in Table 2(a) and 2(b) respectively. Irrigation requirement can be met by planning an irrigation system with PWR of each crop. APMIP has formulated standard PWR of most of the crops which are considered for designing the irrigation systems for different crops in Andhra Pradesh (Narayan, 1995; Oron and Walker, 1981). The planning of irrigation system for the major crops grown in Ananthapur region like groundnut, pigeon pea, maize and tomato during karif and rabi seasons with the available water. With the net depth of irrigation and PWR of particular crop, irrigation frequency has been determined and operating schedules are recommended (George et al., 2000; Montoro et al., 2011).

\section{Dunnikota, Eedulavankagroup CBSIS}

In Eedulavanka group, 19 farmers have entered in to an agreement in which 7 are BWO having 8.9 ha of land and the remaining 8.9 ha is of 12 NBWO. The drawing of design is shown in Figure 2(c). With the available resources at Eedulavanka, the water requirement for different crops during kharif, rabi and for total group area, (BWO site and NBWO site). Available water per day is 621 
$\mathrm{m}^{3} /$ day, the required water for 8.9 ha land is nearly equal to available water during kharif and rabi. Also during the crop period the no. of irrigations required is 10 . Therefore for BWO and NBWO, only 20 days the water has to be pumped during the crop period (except for tomato). For growing tomato, the total water requirement for 8.9 ha of land is $641 \mathrm{~mm}$ and $654 \mathrm{~mm}$ during kharif and rabi and has to be given in 23 irrigations. So, during the crop period of 145 days, total irrigations required is 46 to meet the irrigation requirement of $17.81 \mathrm{ha}$. Therefore according to the availability of water during kharif and rabi, crops can be planned, crop wise water requirement is shown in Table 3 and the design data for sprinkler irrigation system for the group in Table 2(b). If the discharges of the BW still decrease, farmers in the group can plan for tomato as the total water required needs to be distributed in 23 irrigations during 145 days of crop period allowing bore well to recharge and attain the static water level. The crop diversification suggested for Yerraguntla, Mahaboobsubhani group is applicable for Eedulavanka group also.

\section{T Kothapally, Gangireddygroup CBMIS}

The total water available in this group from four borewells is $195 \mathrm{~m}^{3} /$ day, with a land holding 2.43 ha. The BWO land can be irrigated within one day out of 10 days of irrigation interval and the rest of the area which is of NBWO i.e. 7.29 ha can be irrigated in 3 days. The group is having six sprinkler sets from which, two sprinklers sets are operated as a unit and there are 3 units operated for $6 \mathrm{~h} / \mathrm{day}$. Total 2.97ha can be irrigated, but every time while shifting the sprinkler sets time will be wasted since the power is available only for $7 \mathrm{~h}$. So, the effective time of irrigation will be decreased due to waste of time in shifting the unit. The alternative is to increase the sprinkler units or to irrigate the group by sub-dividing it into
0.07 ha patches and follow the sequence to complete one cycle within 10 days of irrigation frequency. BWO can irrigate their lands in one when compared to available water, therefore crop diversification and water sharing is possible (BWO land and NBWO land) during kharif and rabi. Water requirement of different crops for kharif and rabi are detailed in Table 4, design data is shown in Table 2(b) and layout of the field is shown in Figure 2(d). The crop diversification suggested for Yerraguntla, Mahaboobsubhani group is applicable for $\mathrm{T}$ Kothapally group also.

Success of the CBSIS is possible if all the community members are satisfied by getting the optimal yields. So, the present study assessed the operational schedules to utilize the pumped water efficiently and without any bias. Optimal operational plans for kharif and rabi are assessed and recommended. The sprinkler nozzles which are being adopted are discharging more water in less time and leaving swampy areas, also50\% overlapping is ideal for uniform water distribution. The basic infiltration rate of the soil was used as a guide to select a sprinkler with a discharge rate lower than the infiltration rate (25-45 $\mathrm{mm} /$ day), hence it is recommended to change the sprinklers heads which suits the infiltration rate. Comparing the three groups, Mahabubsubhani group has $87 \%$ of NBWO area, whereas Eedulavanka $50 \%$ and in Tkothapally $75 \%$. Following the recommended schedules, it will cover $100 \%$ of the area irrespective of BWO and NBWO, as Mahabubsubhani group can irrigate 14.7 ha/day whereas Eedulavanka group 6.26 ha/day and T Kothapally group 4.7 ha/day. It is advisable to diversify the crop and adapt drip irrigation system at least in bore well owners fields. Crop diversification is recommended by strictly following the operating schedules will result in increase in area of coverage and improvement in yields 
and returns.

\section{Acknowledgements}

Authors express their sincere gratitude to ICAR- Central Institute for Dryland Agriculture and WASSAN (Non-government organization) Hyderabad for the support. Also, the authors acknowledge their gratitude to all the farmers who shared their valuable experiences during the interaction.

\section{References}

Bedeke, S.B. Community-based irrigation water management system: The case of Deder district, East Hararghe, Ethiopia. Adva. Phy. Theo. Appl. 2011, 1, 6-14.

Brouwer, C., Prins, K. and Heibloem, M. Irrigation Water Management: Irrigation scheduling. Training manual no. 4, FAO of the United Nation, Roam. 1989.

Christiansen, J.E. Irrigation by sprinkling. University of California Agricultural Experiment Station. Berkeley, California. 1942. Bulletin 670.

FAO (Food and Agriculture Organization of the United Nations) Irrigation Manual Module 8: Sprinkler irrigation systems design, planning, operation and maintenance. 2001. Savva and Karen Frenken, Irrigation manual.

George, B.A., Shende, S.A. and Raghuwanshi. N.S., Development and testing of an irrigation scheduling model. Agril. Water Mgmt. 2000, 46, 121-136.

Hector, G., Saleem, R., Buba, S., Albert, T. and Richard, D. India Groundwater Governance Case Study, Water Papers. 2011.

Hill, R.W. and Heaton, K. Sprinklers, crop water use and irrigation time. Utah State Uni. Co-oper. Ext. Ser. Bulletin. ENGR/BIE/WM/11.2001.
Knox, J. W., Kay, M. G. and Weatherhead, E. $\mathrm{K}$. Water regulation, crop production, and agricultural water management understanding farmer perspective on irrigation efficiency. Agril. Water Mgmt., 2012, 108, 3-8.

Montoro, A., Fuster, P.L.P. and Fereres, E. Improving on-farm water management through an irrigation scheduling service. Irrig. Sci. 2011, 29, 311-319.

Murty, M.V.R., Singh, P., Wani, S.P., Khairwal, I.S. and Srinivas, K. 2007. Yield Gap analysis of sorghum and pearl millet in India using simulation modeling. Global theme on agroecosystems report No. 37. Patancheru 502 324, Andhra Pradesh, India: International crops Research Institute for the Semi-Arid Tropics. 2017.82p.

Narayan, D. Designing community based development. Social developmental World Bank, Washington, USA. 1995, pp. 7.

Oron, G. and Walker, W. "Optimal design and operation of permanent irrigation system. Water Resources Res. 1981 , 17(1), 11-17.

Pritee A., Bhumika P., Pooja S., Mridubhashini P. and Parameshwar K.S. 2014. Potential of micro irrigation in India: An over view. Int. J. of Agrl. and Food Sci. ISSN 2249-8516.

Rao, C.A.R., Dixit, S., Surendranath, G., Rao, K.V., Reddy, B.S., Samuel, J., Raju, B.M.K. and Venkateshwarlu, B. Enabling a more equitable and efficient groundwater irrigation in rainfed regions of south India. Indian journal of dryland agricultural research and development. 2017, 32(1): 15-20.

Reddy, M.S., Reddy, V.R. and Mohan, R.R. Institutionalizing groundwater management: A tale three participatory models in Andhra Pradesh. Hyderabad: Centre for Economic Studies. 2012. 
Rukmani, R. and Manjula, M. Designing rural technology delivery systems for mitigating agricultural distress: A study of Anantapur district. M.S. Swamynathan Research Foundation, Chennai. 2010.

Seckler, David, Amarasinghe, Upali, Molden, David, deSilva, Radhika, Barker and
Randolph. World Water Demand and Supply 1990 to 2025, Scenarios and Issues. Research Report-19. Int.Water Mgmt. Inst. (IWMI), Colombo, Sri Lanka. 1998.

\section{How to cite this article:}

Deepika, S., K.V. Rao, R. Rejani, B. Krishna Rao and Mukherjee, A.P. 2018. Community Based Sprinkler Irrigation System for Groundwater Sharing in Ananthapur District of Andhra Pradesh, India. Int.J.Curr.Microbiol.App.Sci. 7(09): 3544-3556.

doi: https://doi.org/10.20546/ijcmas.2018.709.440 